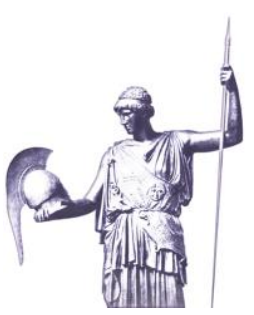

Connections: The Quarterly Journal

ISSN 1812-1101, e-ISSN 1812-2973

Рецензированная статья

В. Шаламанов, П. Анастасов \& Г. Цветков

Connections QJ 18, № 1-2 (2019): 29-50

https://doi.org/10.11610/Connections.rus.18.1-2.02

\title{
Сдерживание и оборона на восточном фланге НАТО и ЕС: готовность и оперативная совмести- мость в контексте вынесенного вперед присутствия
}

\section{Велизар Шаламанов, ${ }^{1}$ Павел Анастасов, ${ }^{2}$ Георги Цветков ${ }^{3}$}

1 Институт ИКТ, Болгарская академия наук, http://www.iict.bas.bg/EN

2 Отдел по политическим вопросам и политике безопасности, Международный секретариат НАTO

3 Национальная военная академия «Г. С. Раковски», София, https://rndc.bg/en/

Резюме: В этой статье отражены дискуссии во время конференции в Софии в сентябре 2018 г., организованной Отделом общественной дипломатии НАТО. Основное внимание в ней уделяется политике обороны и сдерживания НАТО и Европейского союза в Восточной Европе. Особое внимание уделяется развитию Бухарестской инициативы (В9) и ее влиянию на Западные Балканы и Черноморский регион. Авторы предлагают программу обеспечения готовности и оперативной совместимости, ориентированную на область C4ISR. Она основана на состоянии обороны и соответствует контексту развития в НАТО и Европейском союзе, направленного на повышение готовности и оперативной совместимости с партнерами. Эта программа вместе с расширенным сотрудничеством в области образования и обучения для данного региона В9+ будут действовать как инструменты для реализации этого сотрудничества и улучшения сдерживания и обороноспособности на восточном фланге НАТО и ЕС, одновременно повышая устойчивость к гибридным угрозам.

Ключевые слова: НАТО, Европейский Союз, оборона, сдерживание, готовность, оперативная совместимость, сотрудничество, Восточный фланг, Балканы, Черноморский регион, устойчивость. 


\section{Присутствие НАТО в Восточной Европе после перемен 1989 г. ${ }^{1}$}

В этой статье рассматриваются вопросы развития многонациональных формирований в Центральной и Восточной Европе (ЦВЕ)/ Юго-Восточной Европе (ЮВЕ), улучшение их функциональной совместимости и готовности посредством многонациональных проектов, особенно в области коммуникаций и информации (К\&И), а также соответствующее образование и обучение, включая учения. Предлагаются дальнейшие исследования в многонациональном формате для определения программ обеспечения готовности и оперативной совместимости многонациональных формирований в ЦВЕ/ ЮBE.

После изменений 1989 г. НАТО серьезно начало участвовать в делах Восточной Европы, и в 1995 г. началось заметное присутствие в Восточной Европе военных формирований, несущих ответственность перед Организацией Объединенных Наций (OOH) за выполнение Дейтонских мирных соглашений. Эти соглашения были подписаны 22 ноября 1995 года президентами Боснии, Хорватии и Сербии от имени Сербии и Боснийской Сербской Республики. Фактическое подписание состоялось в Париже 14 декабря 1995 года. Соглашения преследовали три основные цели: прекращение боевых действий, принятие военных и гражданских программ и создание центрального боснийского правительства, исключая при этом участие военных преступников в управлении. Первые многонациональные силы (IFOR) под руководством НАТО были созданы для выполнения военных положений Общего рамочного соглашения о мире (GFAP) в Боснии и Герцеговине.

IFOR заменили миротворческие силы OOH (UNPROFOR), которые впервые прибыли в 1992 году, и передача полномочий была согласована в резолюции 1031 Совета Безопасности. В Боснии были развернуты силы НАТО численностью почти в 60000 солдат, в дополнение к силам из стран, не входящих в НАTO. Операция Решительное усилие (SACEUR OPLAN 40105), начавшаяся 6 декабря 1995 года, была подкомпонентом операции Совместное усилие.

Следующим крупным многонациональным присутствием были силы SFOR, которые были созданы резолюцией 1088 Совета Безопасности от 12 декабря 1996 года, чтобы сменить IFOR. K концу 2002 года численность войск была сокращена примерно до 12000 человек, а к концу 2004 года примерно до 7000 человек, когда на Стамбульском саммите НАТО было объявлено об окончании миссии.

Операция "Алтея», официально именуемая «Силы Европейского союза» (EUFOR) в Боснии и Герцеговине, является преемницей SFOR/ IFOR. Переход от SFOR к EUFOR был в значительной степени только сменой названия и командования: 80 \% войск остались на своих местах. Официально они заменили SFOR 2 декабря 2004 года.

1 В этом разделе, в основном, используется информация, опубликованная на вебсайте НАTO, https://www.nato.int, and the English version of Wikipedia. 
Следующим крупным многонациональным формированием, развернутым в Восточной Европе после первой реальной боевой операции НАТО в Европе, ${ }^{2}$ были силы KFOR. После принятия резолюции 1244 Совета Безопасности ООН, войска вошли в Косово 11 июня 1999 года. В то время Косово столкнулось с серьезным гуманитарным кризисом, когда около миллиона человек были вынуждены покинуть свои дома в качестве беженцев. На пике своей численности военнослужащие KFOR насчитывали 50000 человек из 39 стран НАТО и стран, не входящих в НАTO.

С течением времени KFOR постепенно передали ответственность Силам безопасности Косово и другим местным властям, и по состоянию на 23 мая 2016 года насчитывали 4600 военнослужащих. Недавно KFOR в Приштине (2018 г.) состояли из: Группы поддержки штаб-квартиры (HSG) в Приштине; Многонационального специализированного подразделения (MSU) в Приштине (полк военной полиции, полностью состоящий из итальянских карабинеров); Многонациональной боевой группы «Восток» (MNBG-E) в лагере Бондстил возле Ферижая (силы армии США, поддерживаемые Венгрией, Польшей, Румынией и Турцией); Многонациональной боевой группы «Запад» (MMBG-W) в лагере Виладжио Италия недалеко от Печа (силы итальянской армии, поддерживаемые Австрией, Молдовой и Словенией); Объединенной группы логистической поддержки (JLSG) в Приштине (материально-техническое обеспечение и инженерное обеспечение); Тактического резервного батальона KFOR (KTRBN) в лагере Ново Село (полностью состоит из войск Венгерской армии); Объединенного регионального отряда - Север (JRD-N) в лагере Ново Село (местная некинетическая связь и мониторинг); Объединенного регионального отряда - Центр (JRD-C) в Приштине (местная некинетическая связь и наблюдение); Совместного регионального отряда - Юг (JRD-S) в Призрене (местная некинетическая связь и мониторинг).

Опыт, накопленный на Балканах, имел важное значение для определения кризисного менеджмента и использования многонациональных формирований вплоть до тактического уровня. Действуя за пределами Европы, ISAF были многонациональными силами, имевшими решающее значение для разработки концепции оперативной совместимости, особенно с введением сети миссий в Афганистане (AMN) в качестве оперативного инструмента. ${ }^{3}$

Следующая крупная операция - Объединенный защитник - была вызовом и в то же время возможностью проверить готовность и оперативную

2 Gen. Wesley K. Clark, Waging Modern War: Bosnia, Kosovo and the Future of Combat (New York: Public Affairs, 2001).

3 Gen. Stanley McChrystal, My Share of the Task: A Memoir (New York: Penguin Publishing Group, 2013). 
совместимость в воздушном и морском домене. ${ }^{4}$ Задача кризисного менеджмента с оперативной точки зрения решалась с помощью ряда различных инициатив, включая создание Центра управления комплексными операциями в кризисных ситуациях (CCOMC) для обеспечения ситуационной осведомленности и поддержки дальнейшего планирования с помощью имеющихся готовых и оперативно совместимых сил, которые, как правило, являются многонациональными формированиями. ${ }^{5}$

Переход от кризисного менеджмента стал наиболее заметен на саммите в Уэльсе в 2014 году, когда союзники по НАТО согласились реализовать План действий по обеспечению готовности (ПДГ), чтобы быстро отреагировать на фундаментальные изменения в среде безопасности на восточных границах НАТО.

Опираясь на ПДГ, на Варшавском саммите в 2016 году союзники приняли дальнейшие решения по усилению системы сдерживания и обороноспособности НАТО, а также по содействию обеспечения стабильности и укреплению безопасности за пределами территории Североатлантического союза. Вместе эти решения стали самым большим укреплением коллективной защиты Североатлантического союза за последнее поколение. В сочетании с силами и способностями, необходимыми для быстрого подкрепления последующими силами, эти меры повысят безопасность всех союзников и обеспечат защиту территории, населения, воздушного пространства и морских коммуникаций Североатлантического союза, в том числе по ту сторону Атлантического океана, от любых угроз, откуда бы они ни возникали.

Расширенное присутствие НАТО на передовых рубежах носит оборонительный характер, является соразмерным и соответствует международным обязательствам. Оно представляет собой демонстрацию серьезной решимости союзников и является ощутимым напоминанием о том, что нападение на одного - это нападение на всех.

Полностью развернутое в июне 2017 года расширенное передовое присутствие НАТО включает многонациональные силы, предоставленные приграничными государствами и другими участвующими союзниками на добровольной, полностью устойчивой и ротационной основе. Они основаны на четырех сменных боевых группах размером в батальон, которые действуют совместно с национальными силами обороны и постоянно присутствуют в принимающих странах. Канада, Германия, Великобритания и США являются базовыми странами для этого устойчивого многонационального присутствия в Латвии, Литве, Эстонии и Польше, соответственно.

Другие союзники подтвердили свой вклад в эти силы: Албания, Чешская Республика, Италия, Польша, Словакия, Словения и Испания вносят свой вклад в возглавляемую Канадой боевую группу в Латвии; Бельгия, Чешская

4 Rob Weighill and Florence Caub, The Cauldron: NATO's Campaign in Libya (London: Hurst Publishers, 2018).

5 James Stavridis, The Accidental Admiral: A Sailor Takes Command at NATO (Annapolis, Maryland: Naval Institute Press, October 2014). 
Республика, Исландия, Люксембург, Нидерланды и Норвегия присоединились к боевой группе под руководством Германии в Литве; Дания и Исландия участвуют в боевой группе под руководством Великобритании в Эстонии; а Хорватия, Румыния и Великобритания присоединились к боевой группе под командованием США в Польше. Эти расширенные силы передового присутствия дополняются необходимой логистикой и инфраструктурой для поддержки предварительного позиционирования и облегчения быстрого подкрепления. Четыре боевые группы находятся под командованием НАТО через штаб многонационального корпуса «Северо-Восток» в Щецине, Польша. Деятельность этих четырех боевых групп по обучению и подготовке координируется и контролируется штабом многонациональной дивизии «Северо-Восток» (MND-NE) в Эльблонге, Польша.

На саммите 2016 года в Варшаве союзники также договорились развивать адаптированное передовое присутствие в юго-восточной части территории Североатлантического союза. На суше это присутствие строится вокруг многонациональной бригады под руководством Румынии в Крайове. В воздухе несколько союзников усилили деятельность Румынии и Болгарии по защите воздушного пространства НАТО. Это означает больше сил НАТО и больше учений и тренировок под руководством штаба многонациональной дивизии «Юго-Восток» (в Румынии), которая начала действовать в полную силу в июне 2017 года. Это адаптированное передовое присутствие способствует усилению сдерживания и обороны Североатлантического союза и его ситуационной осведомленности, оперативной совместимости и готовности к ответной реакции.

Все эти изменения являются ответом на агрессивное поведение России с 2008 года, но поворотным моментом на самом деле стала аннексия Крыма и агрессивные действия на востоке Украины, а также разработка концепции гибридной войны и ее реализация. Это означает, что на Востоке НАТО сталкивается с гибридным вызовом России, ${ }^{6}$ но в то же время и вполне реальным вызовом со стороны России в области обычных вооружений. ${ }^{7}$

Стратегия НАТО быстрого подкрепления также гарантирует, что силы передового присутствия в случае необходимости будут усилены Совместной оперативной группой очень высокой готовности НАТО, более широкими Силами реагирования НАТО, дополнительными силами высокой готовности союзников и более существенными последующими силами НАТО. НАТО

6 Franklin D. Kramer and Lauren M. Speranza, "Meeting the Russian Hybrid Challenge: A Comprehensive Strategic Framework" (Washington, DC: Atlantic Council, Brent Scowcroft Center on International Security, May 2017), https://www.atlanticcouncil.org/indepth-research-reports/report/meeting-the-russian-hybrid-challenge.

7 Franklin D. Kramer and Hans Binnendijk, "Meeting the Russian Conventional Challenge: Effective Deterrence by Prompt Reinforcement" (Washington, DC: Atlantic Council, Brent Scowcroft Center on International Security, February 2018), www.atlantic council.org/in-depth-research-reports/report/meeting-the-russian-conventionalchallenge. 
также разрабатывает ряд дополнительных мер по увеличению своего присутствия в Черноморском регионе. Осуществляются конкретные меры по усилению морского и воздушного присутствия НАТО в регионе, при этом несколько союзников предоставляют силы и средства. Хотя передовое присутствие в основном сосредоточено в Северо-Восточной Европе, геостратегическое значение Черного моря растет, ${ }^{8}$ особенно для России после аннексии Крыма, и, как следствие, существует видимая конфронтация между Россией и $\mathrm{HATO}^{9}$ в этом регионе.

Основываясь на этом кратком обзоре развития многонациональных сил для кризисного менеджмента, а также для сдерживания и обороны, в оставшейся части статьи исследуется потенциал в ЦВЕ после Брюссельского саммита НАТО (2018 г.) с соответствующими возможностями для повышения готовности и оперативной совместимости через многонациональные коммуникационные и информационные проекты и соответствующее обучение.

\section{Потенциал сдерживания Североатлантического союза в его во- сточной зоне ответственности - путь вперед}

Восточная зона ответственности Североатлантического союза и Черноморский регион продолжают оставаться одним из наиболее динамично развивающихся регионов с одними из самых серьезных проблем в области безопасности. Все они проистекают из агрессивной позиции России на Востоке, Юге Европы и Западных Балканах. После Брюссельского саммита на международной конференции в Софии, Болгария, организованной НАТО в 2018 году, специальная группа по сдерживанию и обороноспособности в Восточной Европе согласилась с тем, что из трех основных задач - коллективная оборона, кризисный менеджмент и совместная безопасность, коллективная оборона остается ключевым направлением деятельности, которое постоянно и быстро развивается благодаря саммитам в Уэльсе, Варшаве и Брюсселе. Эта эволюция описывалась как переход от позиции сдерживания посредством наказания к позиции сдерживания путем воспрещения. Новые решения, принятые на Брюссельском саммите, такие как Инициатива готовности НАТО, а также текущая разработка мер передового присутствия вместе с Европейской оборонной инициативой США (EDI) подтвердили непоколебимую приверженность НАТО коллективной обороне и приверженность США защите Европы.

На конференции представители восточного фланга НАТО отдали приоритет дальнейшему развитию сценария сдерживания путем воспрещения с

8 Bouris Toucas, The Geostrategic Importance of the Black Sea Region: A Brief History, Center for Strategic and International Studies (CSIS), February 2, 2017, www.csis.org/analysis/geostrategic-importance-black-sea-region-brief-history.

9 Boris Toucas, NATO and Russia in the Black Sea: A New Confrontation? Center for Strategic and International Studies (CSIS), March 6, 2017, https://www.csis.org/analysis/ nato-and-russia-black-sea-new-confrontation. 
акцентом на роли формата сотрудничества Бухарест-9 (В9), который должен стать голосом ЦВЕ. ${ }^{10}$ Альянс должен продолжать концентрировать свои усилия на улучшении расширенных военных возможностей, чтобы продемонстрировать надежную способность противостоять агрессии с первого момента. Основное внимание в рамках основной задачи НАТО должно уделяться перспективному планированию, военной мобильности в Североатлантическом союзе и инициативам по обеспечению готовности с передовым присутствием и улучшенной оперативной совместимостью в многонациональной среде на тактическом уровне. Более подробно, этот потенциал сдерживания требует (1) улучшенных систем раннего предупреждения, чтобы дать Североатлантическому союзу больше времени для реагирования, (2) надежных национальных сил, способных вести начальную оборону, и (3) повышенной мобильности и заранее размещенного оборудования для обеспечения массированного ответа Североатлантического союза.

Одним из важных элементов является твердое понимание того, что адаптация НАТО и развитие Европейского Союза (EC) в области обороны должны быть полностью синхронизированы. Преимущества оборонно-промышленного комплекса ЕС и разработка программ оборонных исследований, инструменты, доступные Европейской службе внешних действий, а также разработка проектов PESCO должны согласовываться с разработками НАТО и дополнять друг друга, одновременно обеспечивая и то, и другое и делая НАТО и ЕС сильнее и безопаснее. Европейский Союз должен и впредь наилучшим образом использовать оборонную политику и методологию планирования НАТО. Хорошая координация между НАТО и процессом достижения основных целей ЕС и планом развития потенциала является обязательным условием.

Болгария, Румыния и Турция являются основными заинтересованными сторонами в разработке и реализации текущих мер специально адаптированного передового присутствия НАТО. Эти меры укрепляют сдерживающую и оборонительную позицию Североатлантического союза в Черноморском регионе и должны быть полностью синхронизированы с безопасностью Северо-Восточного / Балтийского региона Восточной Европы (Балтийские государства, Вышеградская группа), связанных с Западными Балканами и Адриатическим морем.

Многонациональная бригада в Крайове с Румынией в качестве базовой нации является основным элементом сухопутного компонента. В воздушной сфере союзники наращивают усилия Румынии и Болгарии по охране воздушного пространства. В морской сфере присутствуют постоянные мор-

10 Marcin Terlikowski, with Veronika Jóźwiak, Łukasz Ogrodnik, Jakub Pieńkowski, and Kinga Raś, "The Bucharest 9: Delivering on the Promise to Become the Voice of the Eastern Flank," PISM Policy Paper no. 4 (164) (Warsaw: Polish Institute of International Affairs, 2018), по состоянию на 29 октября 2018, http://www.pism.pl/Publications/ PISM-Policy-Paper-no-164. 
ские силы НАТО с большим количеством кораблей и военно-морских учений в регионе. В Морском командовании НАТО создан Черноморский функциональный центр. Новая инициатива по расширенному обучению направлена на повышение согласованности всех учебных мероприятий в регионе. Как правило, все специально адаптированные меры должны обеспечивать готовность и совместимость.

Рассматриваемые как сугубо военно-технические вопросы до саммита в Уэльсе, теперь готовность и оперативная совместимость становятся ключевыми критериями эффективности адаптации НАТО к российскому вызову в области обычных вооружений. И именно здесь союзники должны проявить решимость, поскольку готовность и оперативная совместимость обходятся дорого. Необходимо изучить и развить необходимость новаторства и обдумывания рентабельных вариантов для того, чтобы продемонстрировать убедительное сдерживание. Это включает в себя больше ротаций для учений, трансграничную воздушную подготовку (которая может быть основана на модели NORDEFCO), морское присутствие (как на Балтийском, так и на Черном морях) и расширение постоянно дислоцированных формирований.

Болгария должна работать над обеспечением реального и постоянного присутствия сил союзников на своей территории, размещая наземные, воздушные и военно-морские компоненты передового присутствия НАТО, такие как размещение:

- координационного элемента морского командования союзников в Варне, связанного с подразделениями интеграции сил НATO (NFIU) в Софии и Бухаресте;

- многонациональной эскадрильи истребителей ВВС на ротационной основе на болгарской военной авиабазе (особенно в период приобретения нового истребителя и потенциального ускорения снятия с вооружения МиГ-29), которая должна осуществлять совместное союзное воздушное патрулирование болгарского воздушного пространства, потенциально для покрытия воздушного пространства и Северной Македонии после завершения процесса присоединения (в сотрудничестве с Грецией и другими союзниками);

- многонациональной механизированной бригады или многонациональной бригады специальных операций, при этом Болгария должна являться базовым государством.

В качестве выражения солидарности и сплоченности на всем восточном фланге, Болгария должна присоединиться к одной из созданных четырех многонациональных боевых групп НАТО в странах Балтии и Польше.

Новая Инициатива готовности, согласованная на саммите в Брюсселе, должна улучшить способность НАТО мобилизовывать и развертывать более крупные силы подкрепления и, следовательно, усилить сдерживание и обороноспособность на восточном фланге Североатлантического союза. Инициатива должна гарантировать, что в распоряжение НАТО можно будет 
предоставлять более качественные, боеспособные национальные силы в высокой степени готовности. Из общего пула сил союзники предложат дополнительно 30 основных боевых кораблей военно-морских сил, 30 тяжелых или средних маневренных батальонов и 30 авиационных эскадрилий с обеспечивающими силами в готовности не более 30 дней. Они будут организованы и обучены как элементы более крупных боевых формирований в поддержку общего потенциала сдерживания и обороны НАТО. Как указано в коммюнике саммита, Инициатива готовности еще больше усилит возможности быстрого реагирования Североатлантического союза, либо для усиления союзников в поддержку сдерживания или коллективной обороны, в том числе для ведения боевых действий высокой интенсивности, либо для быстрого военного вмешательства в кризисные ситуации, если это необходимо. Это также повысит важность эффективных общевойсковых и совместных операций. Будучи логическим развитием саммита в Уэльсе, План действий по обеспечению готовности и саммит в Варшаве были сфокусированы на передовом присутствии, новой инициативе, которая какой бы амбициозной и важной она ни была, может столкнуться с множеством проблем при реализации.

Ряд областей потребует особого внимания, поскольку увеличение и поддержание боеготовности сил связано с большими затратами. Задача обеспечения 30-дневной готовности также потребует дальнейшего обсуждения, учитывая региональное превосходство России в сухопутных силах. Для таких стран, как Болгария, помимо проблем с предоставлением обученных и оснащенных подразделений, национальные власти должны срочно рассмотреть возможность предоставления поддержки и мобильности, требуемые от принимающей страны. Принимая во внимание, что приобретение новых оперативно совместимых с НАТО истребителей и кораблей в Болгарии было отложено в 2014 году, наиболее очевидным вкладом будет механизированный батальон. Работая в тесном сотрудничестве с Албанией, Черногорией и вскоре, с Северной Македонией, можно будет внести свой вклад в Инициативу готовности созданием региональных многонациональных батальонов для использования Альянсом, что будет способствовать оперативной совместимости и готовности.

Также важно учитывать усилия как НАTO, так и ЕС по повышению военной мобильности на суше, в воздухе и на море, устранению связанных с этим физических барьеров, таких как недостатки инфраструктуры и ее несовместимость с военными требованиями, а также нехватка транспортных средств. Кроме того, необходимо рассмотреть необходимость устранения процедурных препятствий, таких как время для получения национального разрешения на пересечение границы силами и техникой.

Брюссельский саммит подтвердил приверженность обязательствам по инвестициям в оборону, взятым на саммите в Уэльсе в 2014 году. Справедливое разделение бремени лежит в основе сплоченности, солидарности, авторитета Альянса и его способности выполнять обязательства по статьям 
3 и 5. Союзники начали увеличивать суммы, которые они тратят на оборону в реальном выражении, и две трети союзников имеют национальные планы достижения уровня расходов на оборону в объеме 2 \% своего валового внутреннего продукта к 2024 году. Более половины из них выделяют более 20 \% своих оборонных бюджетов на приобретение основного оборудования, включая соответствующие исследования и разработки и, в соответствии с их национальными планами, 24 союзника к 2024 году выполнят норматив в $20 \%$.

Болгария должна пересмотреть и адаптировать планы правительства, для того чтобы достичь уровня расходов на оборону в 2 \% ВВП в 2020 году, а не в 2024 году. Правительство также должно запланировать достижение уровня расходов на приобретение новых способностей и на исследования не менее 20 \% от общих расходов на оборону (и, возможно, для определения варианта увеличения расходов на оборону сверх этих уровней на ранних этапах перевооружения, чтобы ускорить замену старого, несовместимого и часто опасного в эксплуатации советского оборудования). Это должно быть согласовано с достижением договоренности об установлении крайнего срока для прекращения зависимости государств-членов от Российской Федерации в отношении технического обслуживания основных систем вооружений и оборудования, в том числе путем расширения сотрудничества в рамках НАТО и ЕС.

Дополнительной национальной мерой, которую следует здесь рассмотреть, является создание Агентства по закупке вооружений, которое должно быть создано с четко определенными функциями, обязанностями и задачами в соответствии с принципами демократии и надлежащего управления. Создание агентства должно включать механизмы управления проектами и тесную координацию с НАТО и европейскими агентствами по вооружениям и закупкам. В рамках своего мандата оно должно работать над поиском синергии в рамках совместных с союзниками по НАТО / государствами-членами EC на Западных Балканах, в Черноморском регионе и за его пределами возможностей приобретения и обслуживания.

Кроме того, как отметила Лаура Брент в недавней статье в журнале «Вестник НАТО», «киберугрозы безопасности Североатлантического союза становятся все более частыми, силовыми, сложными и разрушительными». ${ }^{11}$ Киберзащита является частью основной задачи коллективной защиты НАТО. Болгария должна иметь возможность действовать в киберпространстве так же эффективно, как и в воздухе, на суше и на море, чтобы укреплять и поддерживать общую политику сдерживания и обороны Североатлантического союза. Таким образом, Болгария может внести важный вклад в сдерживание и защиту, обеспечивая мощную национальную кибер-

11 Laura Brent, "NATO's Role in Cyberspace," NATO Review, 12 February 2019, https://www.nato.int/docu/review/articles/2019/02/12/natos-role-in-

cyberspace/index.html. 
защиту за счет полного выполнения Обязательства по киберзащите, которое имеет решающее значение для повышения киберустойчивости и повышения цены наказания за кибератаки.

Предлагаемая мера для Болгарии-создание центра реагирования на кибер и гибридные угрозы при Министерстве обороны с задачами по расследованию, анализу, а затем координации и реализации мер по противодействию кибер и гибридным угрозам. Этот центр должен быть связан со способностями штаб-квартиры НАТО по раннему предупреждению, а также с соответствующими центрами передового опыта в рамках НАТО и ЕС. Разработка новых правил в ЕС по созданию европейской промышленной, технологической и исследовательской компетенции в области кибербезопасности с сетью национальных координационных центров требует тесной координации с разработками в области обороны на национальном уровне и, соответственно, с НАТО.

Вместе с хорошим сотрудничеством в рамках НАТО и ЕС, важнейшим аспектом успеха является региональное сотрудничество. Группа стран, наиболее озабоченных сдерживанием и защитой восточного фланга НАТО, может быть определена как Бухарест 9+ / В9+ (союзники на восточном фланге, которыми являются Польша, три страны Балтии, Венгрия, Чехия, Словакия, Румыния, Болгария, но также Албания, Черногория и Хорватия с Северной Македонией в качестве будущего государства-члена). В этом формате можно было бы активно взаимодействовать с ключевыми партнерами НАТО, такими как Грузия и Украина. Эти два партнера постоянно заявляли, что они приветствуют усилия Североатлантического союза по обеспечению надежной защиты на его восточном фланге и его приверженность поддержанию стабильности в более широком Черноморском регионе. Хороший пример подобных отношений - отношения между Швецией и Финляндией (являющиеся членами ЕС, но не членами НАTO), которые активно участвуют в проецировании стабильности в регионе Балтийского моря.

Следуя передовой практике NORDEFCO и BENELUX, необходимо и дальше развивать проектное сотрудничество в формате В9. Инициирование флагманской программы обеспечения готовности и взаимодействия (PRI) в этом контексте, как показано ниже, могло бы стать первым шагом к изменениям. Существует большой потенциал для интеграции посредством учений и реальных операций для ряда национальных и многонациональных формирований в регионе. Следуя примеру "решения сперва НАTO», использованного для штаб-квартиры структуры сил HATO, PRI могла бы быть обеспечена полностью за счет поддержки со стороны Агентства связи и информации HATO (NCIA) и Агентства поддержки и закупок HATO (NSPA). Peгиональные проекты по воздушному и морскому наблюдению являются потенциальными пилотными проектами, которые необходимо развивать, а совместный анализ других проектов по осуществлению закупок / логистики в формате В9+ мог бы обеспечить прочную основу для портфеля многонациональных проектов по закупке оборудования или, по крайней мере, для 
региональных систем технического обслуживания и ремонта с поддержкой NSPA.

\section{Развитие инициатив оперативной совместимости и готовности в HATO}

Ростки перемен появились на пражском саммите в ноябре 2002 г., когда НАТО признало важность трансформации вооруженных сил на основе принципов информационного века. Затем был продолжен курс на трансформацию в соответствии с концепцией сетевых способностей НATO (NNEC). Bce операции на Балканах ${ }^{12}$ (Босния и Герцеговина, Косово), а также присутствие в Албании и Македонии дали такой большой опыт, что спровоцировали трансформационные усилия в НАТО с поворотным моментом, основанным на ISAF ${ }^{13}$ и OUP. ${ }^{14}$ В последнее время реализация ПДГ и новой Инициативы готовности придает дополнительный импульс этим усилиям.

Хорошим примером, в 2003 году, было то, как девять стран НАТО (Канада, Франция, Германия, Италия, Нидерланды, Норвегия, Испания, Великобритания и США) организовали финансирование технико-экономического обоснования NNEC. Это исследование было поручено Агентству НАTO C3 (NC3A), а позже АCT запустил информационную кампанию по продвижению концепции NNEC на основе результатов исследования. В то же время в NC3A был создан программный офис NNEC для управления всеми проектами, финансируемыми совместно с NNEC. Достижение полного сотрудничества и полной согласованности между различными проектами НАТО и стран НАТО является долгосрочной целью, поэтому в 2009 году Агентство создало новый спонсорский счет «НАТО и нации» для поддержки реализации проектов C4ISR за пределами командной структуры HATO, связанных с оперативной совместимостью в области К\&И.

Программа NNEC, направленная на создание федерации возможностей на всех уровнях, военном (от стратегического до тактического) и гражданском, через информационную инфраструктуру, и в то же время, следуя видению «Делись, чтобы побеждать», начала работу, направленную на изменение культуры участвующих людей. Обмен информацией является предпосылкой для лучшей ситуационной осведомленности и более быстрого принятия решений, что улучшает сотрудничество между странами, что, в конечном итоге, спасает жизни и ресурсы. Информационная инфраструктура является опорной базой, которая обеспечивает совместную работу и обмен информацией между пользователями, и сокращает время цикла

\footnotetext{
12 Clark, Waging Modern War.

${ }_{13}$ McChrystal, My Share of the Task.

${ }^{14}$ Weighill and Caub, The Cauldron.
} 
принятия решений. Это приводит к информационному превосходству, ${ }^{15}$ то есть способности доставлять нужную информацию нужным людям в нужное время.

В 2009 году Агентство НАТО по консультациям, командованию и управлению (NC3A) признало растущую потребность в поддержке стран в дополнение к общим программам C4ISR (командование, управление, связь, компьютеры, наблюдение и разведка), финансируемых НАТО по разработке современных, интероперабельных и безопасных возможностей C4ISR. Так, 11 ноября 2009 г. Агентство предложило Совету NC3 для нотации Комплексный подход ${ }^{16}$ HATO к C4ISR.

Домен C4ISR / Cyber в контексте сети федеративных миссий (FMN) играет центральную роль в интеграции сил. Для ускорения развития в этой области, особенно для восточноевропейских членов НАТО и партнеров в NC3A (ныне NCIA), в 2010 году было предложено создание Интеграционного фонда ${ }^{17}$ C4ISR. Реализация этой модели началась в 2014 году с трастового фонда C4 для Украины, возглавляемого Канадой, Великобританией и Германией при поддержке $\mathrm{NCIA}$.

В значительной степени инициатива реформирования Агентства в области C4ISR, одобренная на Лиссабонском саммите в 2010 г., продолжала Комплексный подход HATO к C4ISR. Она оказывала поддержку всему сектору безопасности, выходя за пределы оборонного ведомства и включая других партнеров. Она также охватывала весь жизненный цикл C4ISR способностей от определения требований до развертывания и даже вывода из эксплуатации. Кроме того, она использовала все доступные источники финансирования - от общего финансирования до финансирования на основе многонациональных и целевых фондов и финансирования отдельными странами.

В области C4ISR этот комплексный подход обеспечил основу для «Умной обороны» для развития потенциала и предоставления услуг путем моделирования этой области еще до ее объявления в качестве флагманской инициативы НАТО на встрече на высшем уровне в Чикаго в мае 2012 года. Там лидеры НАТО пришли к согласию принять инициативу “Умная оборона» ${ }^{18}$,

15 НАТО определяет информационное превосходство как оперативное преимущество, вытекающее из способности собирать, обрабатывать и распространять непрерывный поток информации, используя или блокируя способность противника делать то же самое.

${ }^{16}$ NATO C4ISR Comprehensive Approach (Brussels: NATO C3 Board and NC3A, 11 November 2009).

17 “Establishment of a C4ISR Integration Fund” (Brussels: NC3A, 2010).

18 Новый подход к расходам на оборону в трудные экономические времена -Умная оборона - был определен генеральным секретарем г-ном Расмуссеном как «обеспечение большей безопасности за меньшие деньги за счет большей гибкости совместной работы». В рамках этого подхода он призывал страны «объединять и делиться возможностями, устанавливать правильные приоритеты и лучше координировать наши усилия». 
чтобы Североатлантический союз мог разрабатывать, приобретать и поддерживать способности, необходимые для достижения целей программы «Силы НАТО 2020», состоящих из современных тесно связанных сил, которые должным образом оснащены, обучены, натренированы и имеют соответствующее руководство.

В цикле Программы развития руководителей высшего звена НАТО (NEDP) 2013-2014 гг. два основных агентства НАТО попросили молодых лидеров НАТО изучить возможности многонационального сотрудничества ${ }^{19}$ при содействии Агентства NCI и NSPA. В цикле NEDP 2015/2016 подразделение оборонных инвестиций использовало тот же механизм для оценки Умной обороны на пять лет вперед. ${ }^{20}$

В качестве элемента «Умной обороны» в агентстве $\mathrm{NCl}$ был разработан подход для поддержки стран в повторном использовании решений НАТО с общим финансированием для принятия более быстрых, совместимых и безопасных решений в области C4ISR. Эта инициатива была представлена на ежегодной конференции СІО в НАTO как программа «НАTО для наций» в поддержку инициатив Генерального секретаря НАТО «Умная оборона» и «Объединенные силы». Реализация этой программы основана на решении "НАТО прежде всего», предлагаемом нациям через Каталог агентств. ${ }^{21}$

И снова Агентство решило воспользоваться классом NEDP 2015/2016 и инициировало исследование по внедрению решения «НАТО прежде всего» 22 в поддержку инициатив "Умная оборона» и “Связанные силы». Первоначально основной движущей силой разработки решения «НАТО прежде всего» для структуры сил HATO (NFS) ${ }^{23}$ была инициатива сети миссий в Афганистане (AMN) в ответ на просьбу генерала Маккристала создать одну сеть командования и управления (C2) для ISAF в 2009 году. ${ }^{24}$

Решения, принятые на саммите в Уэльсе о разработке Плана действий по обеспечению готовности (ПДГ) и его поддержке с помощью подразделений интеграции сил НАTO (NFIU) в восьми восточноевропейских странах НАTO, резко изменили ситуацию с развитием структуры сил НАТО, созданием многонациональных образований и определением модели присутствия на передовых позициях на ротационной основе с расширенной программой учений типа «Связанных учений».

19 "Smarter Smart Defense: Multinational Cooperation Facilitated," NATO Executive Development Program (NEDP) Project Report (NCl Agency and NSPA, NATO HQ, 2014).

20 "Smart Defense: Five Years on - Making Smart Defense Even Smarter!" NEDP project report (Brussels: NATO HQ, NCl Agency, 2016).

${ }^{21}$ Customer Service Catalogue, Part I: Customer Handbook (NCl Agency, 2015).

22 "NATO First: Sharing Alliance Capabilities with Nations," NEDP project report $(\mathrm{NCl}$ Agency, 2016).

23 "NATO 1st Solution for NATO Force Structure" (NCl Agency), accessed October 29, 2018, https://www.ncia.nato.int/Documents/Agency publications/Brochure NATO 1st Solution for NATO Force structure_WEB.pdf.

${ }^{24}$ McChrystal, My Share of the Task. 
Основываясь на опыте, полученном в рамках инициативы «НАТО прежде всего» в поддержке структуры Сил НАТО, многие партнеры НАТО, такие как Финляндия и Швеция, начали использовать инструменты НАТО в своих процессах для усиленных Сил реагирования HATO (eNRF) и реализации ПДГ. Эти усилия включали развертывание восьми NFIU за очень короткий период, параллельно и преобразование системы С2 многонационального корпуса «Северо-Восток» в Польше и развертывание новой штаб-квартиры многонациональной дивизии «Юго-Восток» в Румынии. Для решения этой проблемы был подготовлен отчет из проекта NEDP 7-го цикла «НАTO прежде всего, совместное использование возможностей альянса с государствами» для NCIA, программы поддержки этих различных проектов с разными моделями финансирования, но были установлены аналогичные требования. ${ }^{25}$

С решениями Варшавского саммита по вопросам передового присутствия в Восточной Европе и его усовершенствованных и адаптированных моделей, необходимость более формального управления программой стала очевидна для руководства NCIA и, таким образом, была исследована модель партнерства ${ }^{26}$ для этого начинания.

\section{Готовность и оперативная совместимость НАТО / ЕС в Восточной Европе - перспектива C4ISR}

НАТО приняло Инициативу готовности в $2018^{27}$ году в соответствии с концепцией "Четырех тридцаток», согласно которой к 2020 году союзники смогут иметь 30 механизированных батальонов, 30 авиационных эскадрилий и 30 боевых кораблей, готовых быть задействованы в течение 30 дней или меньше. Это большое изменение началось в Уэльсе в 2014 году с инициирования Плана действий по обеспечению готовности, за которым последовало Варшавское соглашение НАТО о передовом присутствии параллельно с более тесной координацией с ЕС в таких областях, как мобильность, киберзащита, реагирование на гибридные войны и устойчивость в целом. НАТО всегда была альянсом оперативной совместимости между членами, но Инициатива оперативной совместимости, принятая на саммите в Уэльсе (2014 г.), стала платформой для повышения оперативной совместимости также с ключевыми партнерами на основе опыта ИСАФ и других операций.

25 "Initiative for NATO Forces Readiness and Interoperability Partnership (NRIP)," Enclosure 2 to NClA/DM/2016/02367 (NCl Agency, 2016).

26 "NATO 1st Solution (N1S) Concept: Partnership with Customers," Enclosure 3 to NCIA/DM/2016/02367, NCl Agency, 2016.

27 Генеральный секретарь г-н Столтенберг заявил в июне 2018 года: «Речь идет не о создании или развертывании новых сил, а о повышении боеготовности существующих сил». 
В этом контексте и на основе опыта, накопленного с 2002 года (более 15 лет развития), предлагается структура для Программы (Связь и информация) «Готовность и функциональная совместимость (Киберустойчивость)» (PRI) с первоначальным акцентом на страны Бухарест 9 (Болгария, Чехия, Эстония, Венгрия, Латвия, Литва, Польша, Румыния, Словакия). Это страны, которые перешли из Варшавского договора в НАТО и ЕС за последние 20 лет и образуют потенциальную основу наций для ротационных боевых групп и других формирований в рамках передового присутствия, а также других связанных инициатив. Сюда включаются войска США в рамках инициативы «Атлантическая решимость / Европейская оборонная инициamива», а также дальнейшее развитие многонациональных формирований в Восточной Европе, включая развитие KFOR и миссии Алтея как ключевых элементов многонационального военного присутствия в Юго-Восточной Европе.

Такая программа должна начаться с определения структуры сил в Восточной Европе. Сюда могут входить различные элементы NFS, другие многонациональные формирования в рамках инициатив НАТО или ЕС (например, в Юго-Восточной Европе боевая группа HELBROC в составе Греции, Румынии, Болгарии, Кипра и с участием Украины и даже SEEBRIG, созданная в 1999 г. по региональному сотрудничеству в области обороны в ЮВЕ) и элементы национальных силовых структур принимающих стран, которые должны быть включены в такие крупномасштабные усилия по обеспечению оперативной совместимости и готовности.

Заинтересованными сторонами в PRI будут страны, элементы структуры сил которых охватывают и руководство многонациональных формирований, которых это касается, а также стратегическое командование, соответствующие комитеты НАТО, советы и связанные с ними элементы со стороны европейской обороны. Более того, формат В9 (Бухарестское сотрудничество) можно рассматривать как отличную платформу для преобразования сотрудничества между НАТО и ЕС путем внедрения нового подхода к модернизации сил девяти стран, повышения их готовности к операциям НАТО и ЕС, их оперативной совместимости (включая киберустойчивость) и их интеграции с силами передового базирования других стран НАТО / ЕС на ротационной основе, а также участие в любых экспедиционных силах или силах интервенции НАТО или ЕС.

Польша, Румыния и Болгария потенциально могли бы извлечь наибольшую пользу из эффективного и действенного перевооружения и нового уровня готовности и оперативной совместимости силовых структур в ЦВЕ. Это также было бы в целях как НАТО, так и ЕС, но, прежде всего, для сдерживания и защиты на Востоке и, возможно, на Юго-Востоке через настоящую федерацию с системами НАТО / ЕС. В9 обеспечивает прочную основу для развития PRI в качестве практического аспекта сотрудничества, как в контексте НАТО, так и в контексте ЕС при тесной поддержке Агентства связи 
и информации HATO по развитию возможностей C4ISR и предоставлению услуг.

С 2014 года болгарская сторона прилагает усилия для разработки Национальной программы под названием «Болгария в НАТО и европейской обороне» с упором на перевооружение. Сейчас она движется к реальным проектам, одобренными парламентом. Самая последняя из программ - «Видение 2030» - пользуется поддержкой гражданского населения и представляет собой всеобъемлющий и стратегический подход к перевооружению и тесному сотрудничеству с союзниками В9. С точки зрения Болгарии, включение Албании, Черногории и Северной Македонии имеет решающее значение, и в сотрудничестве с Грецией это изменит состояние обороны в регионе. Следующим шагом будет взаимодействие с Боснией и Герцеговиной, Косово и Сербией.

Будучи членами как НАТО, так и ЕС, страны В9 могут гармонизировать свои требования и использовать все доступные инструменты НАТО, ЕС и многонациональные / региональные инструменты для создания наилучших возможных C4ISR / кибер-способностей для своих вооруженных сил в контексте многонациональных силовых структур НАТО / ЕС. Помимо В9, участие стран Адриатики, таких как Албания, Хорватия, Черногория, Словения и Северная Македония (скоро станет 30-м членом НАТО), а также некоторых черноморских кандидатов на членство в НАТО / ЕС, таких как Украина и Грузия (и даже Молдова), может рассматриваться в рамках договоренностей о партнерстве.

В этом контексте программа «Готовность и оперативная совместимость» для стран $89+$ с участием ведущих боевых групп и / или сменных сил из других стран НАТО в регионе является логичным. Программа может поддерживаться NCIA в контексте решения «НАTO прежде всего» при финансировании со стороны клиентов (включая доступное общее финансирование из существующих и будущих целевых фондов (4). В прошлом и, безусловно, в будущем, основные усилия в рамках PRI будут включать в себя множество индивидуальных, но неотложных и связанных с операциями действий и запросов на учения, предполагающих быстрое реагирование.

$\mathrm{NCIA}$ провела исследование внешней (не финансируемой из общих источников) поддержки клиентов с Промышленным консорциумом сетецентрических операций (NCIOC), чтобы определить наиболее адекватную модель, основанную на лучших отраслевых практиках для решения этой проблемы. Это хорошая основа для оказания поддержки внешним клиентам в рамках PRI без вмешательства в общие финансируемые программы.

Очевидно, что область C4ISR / Кибер стимулирует инновации не только в области технологий, но и во всех других аспектах, включая бизнес-модели для сотрудничества и развитие необходимых институтов, чтобы сделать эти усилия успешными для всех. В этом контексте дискуссии о трансформации союзного командования НАTO (NCIOC-ACT) в плане внедрения проверки 
оперативной совместимости до приобретения товаров и услуг создают дополнительные стимулы для PRI. В рамках Инициативы по проверке функциональной совместимости могут быть начаты новаторские проекты по разработке нового стандарта в практике закупок, который исследует функциональную совместимость на уровне организации для сетевой среды федеративных миссий. Ожидается, что это сэкономит миллиарды евро для НАТО, его членов и партнеров с очевидными преимуществами для стран $\mathrm{B} 9+$

Итак, теперь есть возможность рассмотреть проекты и программы, связанные с C4ISR / Кибер в странах B9+ в контексте реализации ПДГ / ПП и Инициативы обеспечения готовности / Инициативы обеспечения оперативной совместимости, а также консолидировать работу в контексте НАТО / ЕС для экономии денег. Возможно, более важной будет способность достичь высокого уровня оперативной совместимости, безопасности и готовности систем С2 на восточном фланге с включением стран региона в ротацию войск с участием членов и стран-партнеров. Штаб-квартира НАТО, стратегическое командование, NCIA могут сыграть свою роль, но ответственность принадлежит странам B9 с привлечением промышленности и исследовательских институтов для трансформации PRI. Кроме того, PRI принесет пользу европейским оборонным разработкам.

С момента своего создания в 2012 году Агентство $\mathrm{NCl}$, объединив пять различных агентств К\&И НАТО, провозгласило инициативу для национальных главных директоров по информационным технологиям (ClO) вместе с представителями ACO, АСТ и штаб-квартиры НАTO в NFS, исследовательскими учреждениями и промышленности, чтобы определить наиболее эффективный, действенный и устойчивый к кибер воздействию способ обеспечения взаимодействия и готовности в области К\&И. Их, ставшие уже традиционными, ежегодные конференции ИТ-директоров ${ }^{28}$ проложили путь к реализации решения «НАТО прежде всего» и достижению оперативной совместимости и готовности в безопасной среде быстрыми, простыми и доступными способами (HATO R\&I SAFE).

Определение PRI как результата обзора требований под руководством НАТО / ЕС с активным внедрением решений, совместимых с FMN в сотрудничестве с промышленностью и NCIA в качестве исполнительного / вспомогательного агентства, выведет практические аспекты оперативной совместимости и готовности на новый уровень в Центральной и Восточной Европе. PRI необходимо полностью синхронизировать со всеми учениями с участием сил в ЦВЕ, с операциями, миссиями, деятельностью и задачами НАТО / ЕС не только для постоянного улучшения оперативной совместимости и готовности, но и для того, чтобы они могли внести реальный вклад в сдерживание и оборону. Параллельно следует рассмотреть возможность

${ }^{28}$ Информацию о каждой из конференций серии «Конференции директоров по информационным технологиям» можно найти на сайте агентства $\mathrm{NCl}$ https://www.ncia.nato.int. 
распространения PRI на все «новые» страны HATO в ЦВЕ, а также определить партнеров PRI для поддержки работы с партнерами в ЦВЕ (включая Западные Балканы и регион Черного моря).

Концептуализация охвата и руководства / управления PRI может быть осуществлена в более широкой среде консультаций с представителями промышленности и НПО, но реальные шаги могут быть предприняты только странами или структурами ЕС, связанными с АСО / АСТ. Конечно, существующие модели, реализованные для среды AMN / FMN как распределенная сеть боевых лабораторий (DNBL) в качестве инструмента для поддержки программы, также будут использоваться для формирования программы.

\section{Образование и обучение как основные инструменты для дости- жения оперативной совместимости. Последствия для Западных Балкан и Черноморского региона}

Когда речь идет о готовности и совместимости, особенно многонациональных образований, речь идет не только об оборудовании, но и о людях, их образовании и обучении. Это причина рассматривать сеть многонациональных формирований в ЦВЕ как инструмент для развития сотрудничества в области образования и обучения, сертификации и развития персонала. Очевидно, что для многонациональных формирований, в том числе на тактическом уровне (например, батальонные боевые группы, авиаэскадрильи, корабли, включенные в инициативу готовности), рабочим языком будет английский, процедуры будут базироваться на практике НАТО и для систем С2 потребуются решения «НАТО в первую очередь».

По этим причинам синхронизация программ обучения и подготовки офицеров, сержантов и даже солдат должна достигаться в соответствии со стандартами НАТО. Не менее важен опыт ротации в многонациональных подразделениях. Консорциум академий обороны и институтов по изучению вопросов безопасности «Партнерство ради мира» вместе с Программой повышения оборонного образования НАТО уже многое дает благодаря совместной работе над справочными учебными планами в различных областях. ${ }^{29}$ Эти учебные программы сближают профессиональное военное образование союзников по НАТО и их партнеров, повышая уровень стандартизации, а также улучшая интеллектуальную совместимость. То же самое можно сказать и об усилиях Европейского колледжа безопасности и обороны, ко-

${ }^{29}$ CM. "Generic Officer Professional Military Education - Reference Curriculum," "Cybersecurity - A Generic Reference Curriculum," and "Non-Commissioned Officer Professional Military Education - Reference Curriculum," все доступны на вебсайте НАTO, https://www.nato.int. 
торый является частью Европейской службы внешних связей. Он сосредоточил усилия на внедрении единых стандартов в образование и подготовку в рамках профессионального военного образования во всем EC. ${ }^{30}$

Хотя часто бывает важно различать образование и обучение, в этой статье высказывается мнение, что они являются взаимовключающими видами деятельности. Для полноценного развития военнослужащих необходимы образование и обучение, а также опыт. Оперативная совместимость как в образовании, так и в обучении - это критически важная дорога, позволяющая вооруженным силам нации соответствовать требованиям национальной безопасности и выполнять их в условиях международной безопасности, где решающее значение имеет тесное сотрудничество с союзниками и партнерами. Отсюда и предложение сконцентрировать дальнейшие усилия НАTO и ЕС на Западных Балканах и в Черноморском регионе для решения текущих проблем безопасности посредством академического диалога и взаимодействия в профессиональном военном образовании и обучении. Это обеспечит прочную основу для сдерживания и обороны и для проецирования стабильности в этих регионах.

\section{Заключение: региональное сотрудничество (SEDM / A5 и B9): Возможна ли консолидация?}

Анализ развития присутствия НАТО / ЕС в Центральной и Восточной Европе, особенно через многонациональные формирования - от KFOR до боевых групп eFP в странах Балтии и Польше, боевых групп EC (таких как HELBROC в Юго-Восточной Европе) на Первом уровне, за которым следуют штаб-квартиры уровня дивизии / корпуса и вплоть до NCS - обеспечивает исходные данные для определения требований к взаимодействующим системам С2 на тактическом уровне, напрямую связанных с оперативным / стратегическим уровнем и соответствующими требованиями к обучению персонала в этих многонациональных формированиях.

Еще более серьезной является задача определить дорожную карту для развития этих многонациональных формирований в Восточной Европе в рамках НАТО / ЕС с участием западноевропейских и североамериканских членов Атлантического альянса. Важно подчеркнуть, что многонациональность на тактическом уровне - в батальонах, эскадрильях и кораблях - это самое главное. Это потому, что речь идет о реальном использовании процедур НАТО на повседневной основе, системах С2 и демонстрации солидарности. Эти тактические подразделения, будучи многонациональными, будут моделью для национальных подразделений того же типа или размера, но, находясь под многонациональным управлением, системы С2 будет под-

${ }^{30}$ European Security and Defense College (ESDC), "Standard Curricula," по состоянию на 29 октября 2018, https://eeas.europa.eu/topics/common-security-and-defensepolicy-csdp/4369. 
держивать готовность и оперативную совместимость, требуемые Инициативой готовности, и поэтому они будут иметь больше шансов быть привлеченными к участию в операциях без каких-либо оговорок.

Основываясь на большом пуле многонациональных тактических формирований, намного проще назначить многонациональные штаб-квартиры более высокого уровня для управления обучением и подготовкой, а также для планирования и С2 в случае активации. Такие организации будут содействовать многонациональным проектам по оперативно совместимым системам C4ISR и другому оборудованию и / или вооружениям. Эти многонациональные проекты могли бы управляться расширенными национальными агентствами, но, возможно, даже лучший вариант - использовать NCIA / NSPA.

И последнее, но не менее важное - это организация образования и обучения, охватывающая все аспекты от индивидуального до коллективного и от полевого обучения до компьютерных учений.

Основной посыл этой статьи заключается в том, что если НАТО хочет достичь зрелости путем консолидации существующих структур многонациональных формирований и разработки дорожной карты для ее дальнейшего развития в ЦВЕ / ЮВЕ с особым акцентом на многонациональные проекты C4ISR и совместное обучение и подготовку, ориентированные на оперативную совместимость и готовность, ландшафт безопасности и обороны может быть резко изменен. В регионе могут произойти настоящие преобразования в сфере обороны, и в результате общая устойчивость будет повышена.

Необходимы дальнейшие исследования для разработки бизнес-обоснования Программы готовности и взаимодействия, для определения модели руководства и управления программой, технологических дорожных карт и конкретных требований к образованию и обучению (включая учения), а также для реализации передового присутствия в ЦВЕ / ЮВЕ, что будет способствовать сотрудничеству между НАТО и ЕС и региональному сотрудничеству.

\section{Отказ от ответственности}

Выраженные здесь взгляды являются исключительно взглядами авторов и не отражают точку зрения Консорциума оборонных академий и институтов изучения безопасности ПрМ, участвующих организаций или редакторов Консорциума.

Издание Connections: The Quarterly Journal, том 18, 2019 осуществляется при поддержке правительства Соединенных Штатов. 


\section{O6 авторах}

После 19 лет службы в армии доктор Велизар Шаламанов начал научную карьеру в Академии наук, а также несколько раз работал на государственных должностях: заместитель министра обороны (1998-2001 гг.), министр обороны (2014 г.) и директор по менеджменту спроса в Агентстве кибер и информационных технологий НАТО (2009-2017). В настоящее время он занимается консолидацией академического кибер потенциала Болгарии. Параллельно он участвует в политике и в работе неправительственных организаций, стремящихся к улучшению позиции Болгарии в НАТО и в европейской обороне, в информационном обществе и к улучшению управления научными исследованиями. E-mail: shalamanov@acad.bg.

Г-н Павел Анастасов возглавлял Отдел стратегической политики и анализа Кабинета Президента Республики Болгария в период 2012-2014 гг. В 2014 году он занимал должность заместителя министра обороны. В период с 2014 по 2018 год он работал над вопросами безопасности Черного моря в отделе по политическим вопросам и политике безопасности в штаб-квартире НАTO.

Д-р Георгий Цветков - доцент в Национальной военной академии «Г. С. Раковски» в Софии, занимается различными темами в области управления обороной, развития способностей и политики безопасности. 